\title{
Kesembuhan Fraktur Tulang Femur Kelinci Pascaimplantasi Bahan Cangkok Demineralisasi Serbuk Tulang Sapi Bali
}

\author{
(HEALED FRACTURE OF RABBIT FEMUR POST IMPLANTATION WITH \\ DEMINERALIZED GRAFT MATERIAL OF BALI CATTLE BONE POWDER)
}

Ni Putu Trisna Asih ${ }^{1 *}$, I Wayan Wirata ${ }^{2}$, Luh Made Sudimartini ${ }^{3}$, Ida Bagus Oka Winaya ${ }^{4}$, I Made Kardena ${ }^{4}$, I Wayan Gorda ${ }^{2}$

\author{
${ }^{1}$ Praktisi Dokter Hewan di Blahbatuh, Batuan Kaler, Sukawati Gianyar, Bali, \\ Indonesia 80582; \\ ${ }^{2}$ Laboratorium Bedah Veteriner, Fakultas Kedokteran Hewan Universitas Udayana, \\ Jl. PB Sudirman, Denpasar, Bali, Indonesia 80225; \\ ${ }^{3}$ Laboratorium Farmasi Veteriner, Fakultas Kedokteran Hewan Universitas Udayana, \\ Jl. PB Sudirman, Denpasar, Bali, Indonesia 80225; \\ ${ }^{4}$ Laboratorium Patologi Veteriner, Fakultas Kedokteran Hewan Universitas Udayana, \\ Jl. PB Sudirman, Denpasar, Bali, Indonesia 80225. \\ *Email: trisnaaasih@gmail.com
}

\begin{abstract}
ABSTRAK
Tujuan penelitian ini untuk mengetahui gambaran mikroskopis kesembuhan fraktur tulang femur kelinci pascaimplantasi dengan bahan cangkok demineralisasi serbuk tulang sapi bali. Kelinci lokal jantan sebanyak 12 ekor digunakan dalam penelitian ini yang dibagi menjadi dua kelompok secara acak. Kelompok A adalah tiga ekor kelinci yang digunakan sebagai kontrol, yaitu kelinci pada diaphysis tulang femurnya dibor dengan diameter $5 \mathrm{~mm}$ dan kedalaman bor hingga mencapai medula, tanpa pemberian bahan cangkok. Kelompok B adalah 9 ekor kelinci yang dibor seperti kelompok A dan diberikan serbuk cangkok tulang pada bagian tulang yang dibor. Pada minggu ke-2, ke-4, dan ke6 pascaoperasi dilakukan biopsi tulang masing-masing satu ekor kelinci pada kelompok A dan tiga ekor kelinci pada kelompok B. Pengamatan mikroskopis dilakukan dengan membuat sediaan tulang diwarnai dengan Hematoksilin-Eosin (HE). Hasil penelitian menunjukkan bahwa proses kesembuhan tulang lebih cepat terjadi pada kelompok B yang diamati dari minggu ke- 2 sampai minggu ke-6 dengan sel radang terlihat sedikit dan jumlahnya berkurang setiap pengamatan, adanya pertumbuhan osteoblas, osteoklas, osteosit, kartilago, tulang trabekula, neovaskularisasi dan proliferasi fibrolas lebih cepat dibandingkan kelompok A. Dapat disimpulkan, bahan cangkok asal tulang sapi bali mampu menginduksi proses kesembuhan tulang fraktur pada kelinci.
\end{abstract}

Kata kunci: cangkok tulang; sapi bali; demineralisasi; kelinci; histopatologi

\begin{abstract}
The purpose of this study to determine the microscopic changes in rabbit femur fracture healing post-implantation of the graft material demineralized powder bone of bali cattle. Twelve local male rabbits were divided into two groups randomly. Group A consisted of three rabbits used as a control, in which the diaphysis rabbit femur bones were drilled with a diameter of $5 \mathrm{~mm}$ and depth of drill to reach the medulla, without giving graft material. Group B nine rabbits that were drilled the same as group A and given a powder bone graft. Monitoring progress of bone healing was done in a row against one rabbits in group A and group B three rabbits at week $2^{\text {nd }}, 4^{\text {th }}$, and $6^{\text {th }}$ post-surgery with biopsy for sampling bone subsequently prepared to see microscopic changes the bone with using hematoxylineosin (HE) staining. The results showed that the group B bone healing observ by reducing inflammation, proliferation of fibrolast, osteoblasts, osteoclasts, osteocytes, woven bone, trabecular bone, and neovascularization. In conclusion, the origin of the bone graft material bali cattle was able to induce the healing process of bone fractures in rabbits.
\end{abstract}

Keywords: bone graft; bali cattle; demineralization; rabbits; histopathology. 


\section{PENDAHULUAN}

Hewan kesayangan sering dibawa ke klinik hewan maupun rumah sakit hewan untuk pemeriksaan kesehatan secara rutin atau karena trauma yang serius yang diakibatkan oleh kecelakaan. Trauma akibat kecelakaan dapat menimbulkan kerusakan seperti fraktur atau patah tulang. Fraktur merupakan hilangnya kesinambungan tulang baik secara utuh maupun sebagian pada jaringan tulang yang mengalami cidera, kondisi demikian memerlukan penanganan serius, terutama pada kondisi tulang yang patah menjadi beberapa fragmen.

Prinsip penanganan fraktur adalah dengan mereposisi atau mengembalikan posisi tulang yang patah ke posisi semula dan mempertahankan posisi tersebut (imobilisasi) supaya proses penyembuhan terjadi dengan baik dan benar. Pada fraktur multiple, patahan tulang kecil dan sulit untuk disatukan kembali menggunakan pin ataupun eksternal fiksator, maka diperlukan metode khusus, yaitu pencangkokan tulang (bone grafting) (Wirata et al., 2016). Material bahan cangkok tulang yang ideal harus memiliki potensi untuk mempertahankan sel tetap hidup, tidak menimbulkan reaksi imunologik, mudah didapat, memberi kekuatan sekeliling tulang, dan tidak menyebarkan penyakit (Greenwald et al., 2008). Tulang sapi sering digunakan sebagai bahan cangkok xenograft pada kasus ortopedik (Heo et al., 2011). Penggunaan serbuk tulang sapi bali sebagai bahan cangkok belum pernah diaplikasikan pada kelinci. Berdasarkan hal tersebut maka diteliti tentang pemanfaatan tulang femur sapi bali (Bos sondaicus) sebagai bahan dasar bone Xenograft yang diproses dengan menghilangkan kadar mineralnya (demineralisasi) untuk mengetahui gambaran histopatologi kesembuhan fraktur tulang femur kelinci pascaimplantasi bahan cangkok demineralisasi serbuk tulang sapi bali.

\section{METODE PENELITIAN}

Penelitian menggunakan 12 ekor kelinci jantan lokal dengan berat kisaran $2.500 \mathrm{~g} \pm 500 \mathrm{~g}$, dibagi menjadi 2 kelompok. Kelompok A adalah 3 ekor kelinci yang digunakan sebagai kontrol, yaitu kelinci pada diaphysis tulang femurnya dibor dengan diameter $5 \mathrm{~mm}$ dan kedalaman bor hingga mencapai medula, tanpa pemberian bahan cangkok. Kelompok B adalah 9 ekor kelinci yang dibor seperti kelompok A dan diberikan serbuk cangkok tulang pada tulang yang dibor. Monitoring perkembangan kesembuhan tulang dilakukan berturutturut terhadap 1 ekor kelinci kelompok A dan 3 ekor kelinci kelompok B pada minggu ke-2, ke-4, dan ke-6 pascaoperasi dengan dilakukan biopsi untuk pengambilan sampel tulang yang selanjutnya dibuatkan preparat dengan pewarnaan Hematoksilin-Eosin (HE) sesuai dengan metode keirnan untuk melihat perubahan histopatologi tulang tersebut. Indikator keberhasilan penggunaan bahan cangkok dapat dilihat melalui proliferasi jaringan fibroblas, kartilago, adanya osteoblas, osteoklas, osteosit, adanya neovaskularisasi, tulang trabekula dan tidak ditemukannya sel radang (Puricelli et al., 2010; Wildmann et al., 2007).

\section{Pembuatan Bahan Cangkok Demineralisasi}

Pembuatan bahan cangkok asal tulang kortek sapi melalui proses demineralisasi, dengan cara sebagai berikut: tulang dibersihkan dari sisa otot dan jaringan lemak menggunakan scalpel, tulang dipotong dengan ukuran $0,5 \times 0,5 \mathrm{~cm}$, selanjutnya dihancurkan dengan palu untuk menghasilkan serbuk. Hasil berupa serbuk tulang kemudian dicuci menggunakan aquades dan selanjutnya dengan $\mathrm{NaCl} 0,9 \%$. Serbuk yang sudah dibersihkan kemudian direndam selama 12 jam menggunakan klorofom-methanol (rasio 1:1) untuk menghilangkan lemak (defattening) dan protein (deproteinizing). Kemudian serbuk direndam dalam $\mathrm{HCl}$ $5 \%$ selama 72 jam pada suhu ruangan dan larutan $\mathrm{HCl}$ diganti setiap 12 jam dengan 
perbandingan berat serbuk dan volume larutan adalah $50 \quad \mathrm{gr} \quad: \quad 500 \quad \mathrm{ml}$. Demineralisasi yang sempurna ditandai dengan konsistensi serbuk tulang menjadi lunak dan translucent (transparan), kemudian serbuk tulang dicuci menggunakan aquades sampai bersih dan dilanjutkan pencucian menggunakan alkohol $70 \%$, kemudian dimasukkan dan disimpan dalam tabung yang berisi alkohol $70 \%$ sampai diaplikasikan.

\section{Demineralisasi Serbuk Tulang}

Sebelum tindakan operasi dimulai kelinci diberikan anestesi kombinasi xylazine-ketamine dengan masing-masing dosis $5 \mathrm{mg} / \mathrm{kg}$ dan $35 \mathrm{mg} / \mathrm{kg}$ secara intramuskular (Hrapkiewicz et al., 2013; Enezei et al., 2014; Azam et al., 2016). Setelah kelinci teranestesi, rambut di daerah femur dicukur dan diolesi alkohol $70 \%$ dan larutan iodine povidone. Kemudian kelinci diposisikan rebah lateral pada meja operasi. Pembuatan model fraktur dilakukan dengan cara membuat insisi kulit di sepanjang craniolateral tulang yang segaris dari trochanter mayor ke patella. Demikian pula pada bagian subkutan. Kulit dan jaringan subkutan diretraksi, fascia lata diiris sepanjang tepi cranial $M$. biceps femuris. Setelah fascia diiris maka tampak septum muskulus. $M$. biceps femuris ditarik ke belakang dan $M$. vastus lateralis ditarik ke depan sehingga tampak bagian permukaan tulang femur. Dengan menggunakan mesin bor tulang (boor low speed), diaphysis tulang femur setiap kelompok dibuat lubang dengan diameter $5 \mathrm{~mm}$ dan dibor hingga menembus medula. Selama proses operasi dijalankan, tulang ditetesi dengan larutan fisiologis $\mathrm{NaCl}$ untuk mencegah kerusakan akibat panas (Azam et al., 2016). Pada kelompok A, bagian diaphysis tulang femur yang dibor tidak diberikan bahan cangkok, dan kelompok $\mathrm{B}$ bagian diaphysis tulang femur yang dibor selanjutnya diaplikasikan bahan cangkok serbuk demineralisasi. Setelah itu muskulus dijahit dengan menggunakan cat gut chromic ukuran 0000 dan kulit dengan menggunakan benang silk 3-0. Perawatan pascaoperasi, kelinci diletakkan pada alas yang nyaman dan diberikan injeksi antibiotika berupa enrofloxacin dengan dosis $10-30 \mathrm{mg} / \mathrm{kg}$ injeksi secara IM/SC selama 7 hari (Mapara et al., 2012). Untuk mengatasi rasa sakit, kelinci diberikan carprofen dengan dosis $1,5 \mathrm{mg} / \mathrm{kg}$ per oral selama 7 hari (Mapara et al., 2012).

\section{Analisis Data}

Hasil penelitian dianalisis secara deskritif kualitatif melalui pengamatan gambaran mikroskopis menggunakkan mikroskop pembesaran 10x dan 40x pada 5 lapang pandang pengamatan.

\section{HASIL DAN PEMBAHASAN}

Kesembuhan fraktur tulang femur kelinci pascaoperasi pada kedua kelompok mengalami pertumbuhan kalus, pertumbuhan sel lebih cepat terjadi pada kelompok B yaitu pada minggu ke-2 lokasi implan mulai ditemukan kalus interna dengan adanya fibroblas, neovaskularisasi dan terlihat sedikit sel radang, pada minggu ke-6 kesembuhan terjadi secara maksimum ditandai dengan lokasi implan woven bone digantikan oleh tulang kompak dan memenuhi ruang fraktur dengan peningkatan osteoblas, osteosit serta sel radang yang sudah tidak terlihat, hasil pengamatan mikroskopis kesembuhan tulang femur pada kedua kelompok disajikan pada tabel 1 dan gambar 1-6.

Berdasarkan hasil pengamatan gambaran histopatologi, pada minggu kedua ditemukan adanya infiltrasi sel radang di sekitar daerah tulang femur yang diberikan cangkok maupun tanpa cangkok (Gambar 1 dan 2). Hal ini disebabkan karena pada minggu kedua masih merupakan fase inflamasi pada proses kesembuhan fraktur. Fase inflamasi dapat terjadi 1-2 minggu pasca operasi (Kaewloet 2008). 
Tabel 1. Hasil pengamatan mikroskopis kesembuhan tulang femur kelompok A dan kelompok B pasca implantasi bahan cangkok demineralisasi serbuk tulang sapi bali.

\begin{tabular}{|c|c|c|c|}
\hline \multirow[t]{2}{*}{ Perlakuan } & \multicolumn{3}{|c|}{ Minggu ke- } \\
\hline & 2 & co & 6 \\
\hline $\begin{array}{l}\text { Kelompok } \\
\text { A }\end{array}$ & $\begin{array}{l}\text { Adanya banyak sel } \\
\text { radang (makrofag, } \\
\text { limfosit,neutrofil), } \\
\text { sel lemak dan } \\
\text { neovaskularisasi }\end{array}$ & $\begin{array}{l}\text { Adanya tulang trabekula, } \\
\text { kartilago, fibroblas dan sel } \\
\text { lemak serta sedikitnya sel } \\
\text { radang }\end{array}$ & $\begin{array}{l}\text { Adanya tulang } \\
\text { trabekula, kartilago, } \\
\text { fibroblas, } \\
\text { neovaskularisasi }\end{array}$ \\
\hline $\begin{array}{l}\text { Kelompok } \\
\text { B }\end{array}$ & $\begin{array}{l}\text { Adanya fibroblas, } \\
\text { neovaskularisasi, } \\
\text { osteoklas, spikula } \\
\text { serta terlihat } \\
\text { sedikitnya sel radang }\end{array}$ & $\begin{array}{l}\text { Adanya tulang trabekula, } \\
\text { kartilago, neovaskularisasi, } \\
\text { fibroblas, osteosit, dan } \\
\text { osteoblas serta tidak } \\
\text { terlihat sel radang }\end{array}$ & $\begin{array}{l}\text { Adanya tulang } \\
\text { trabekula, } \\
\text { neovaskularisasi, } \\
\text { fibroblas, peningkatan } \\
\text { osteoblas, dan osteosit }\end{array}$ \\
\hline
\end{tabular}
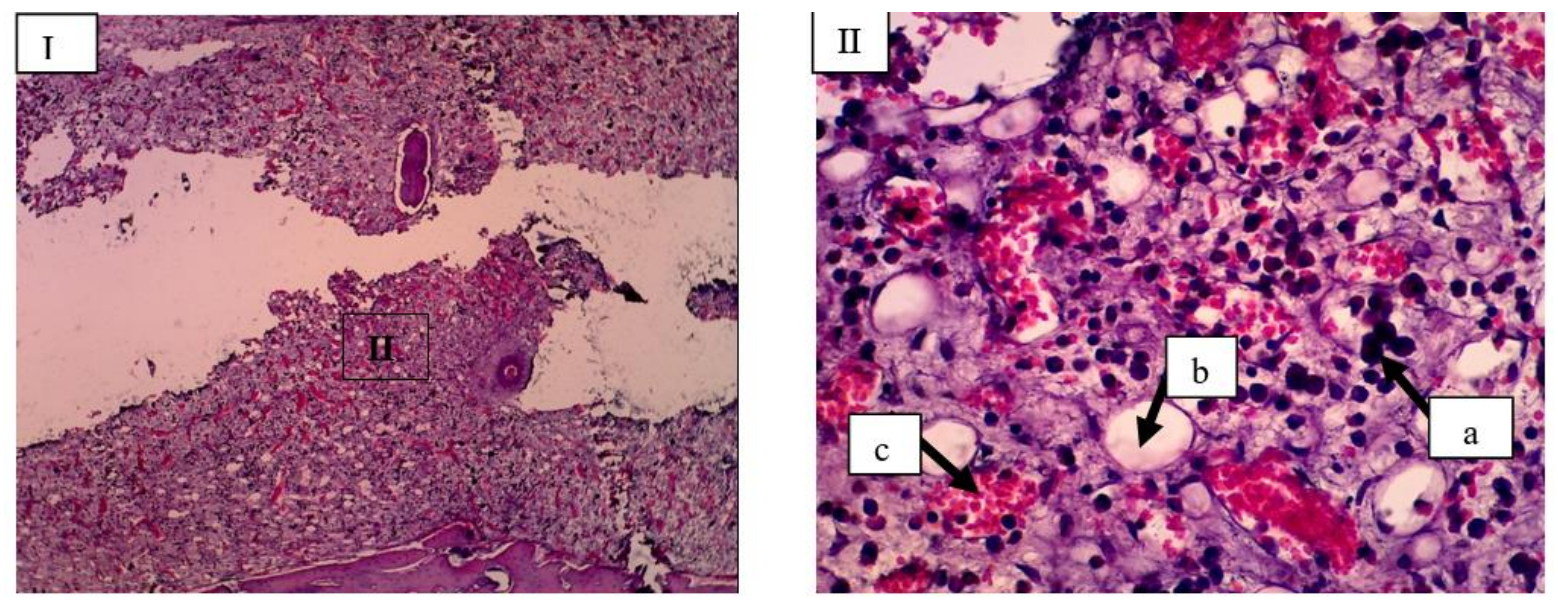

Gambar 1. Gambaran mikroskopis tulang kelinci kelompok kontrol (Kelompok A) minggu ke2. Pada lokasi fraktur belum ditemukan pertumbuhan kalus dan terlihat hanya adanya banyak sel radang (Makrofag) (a), sel lemak (b) dan neovaskularisasi (c) (I: HE 10x; II: HE 40x).
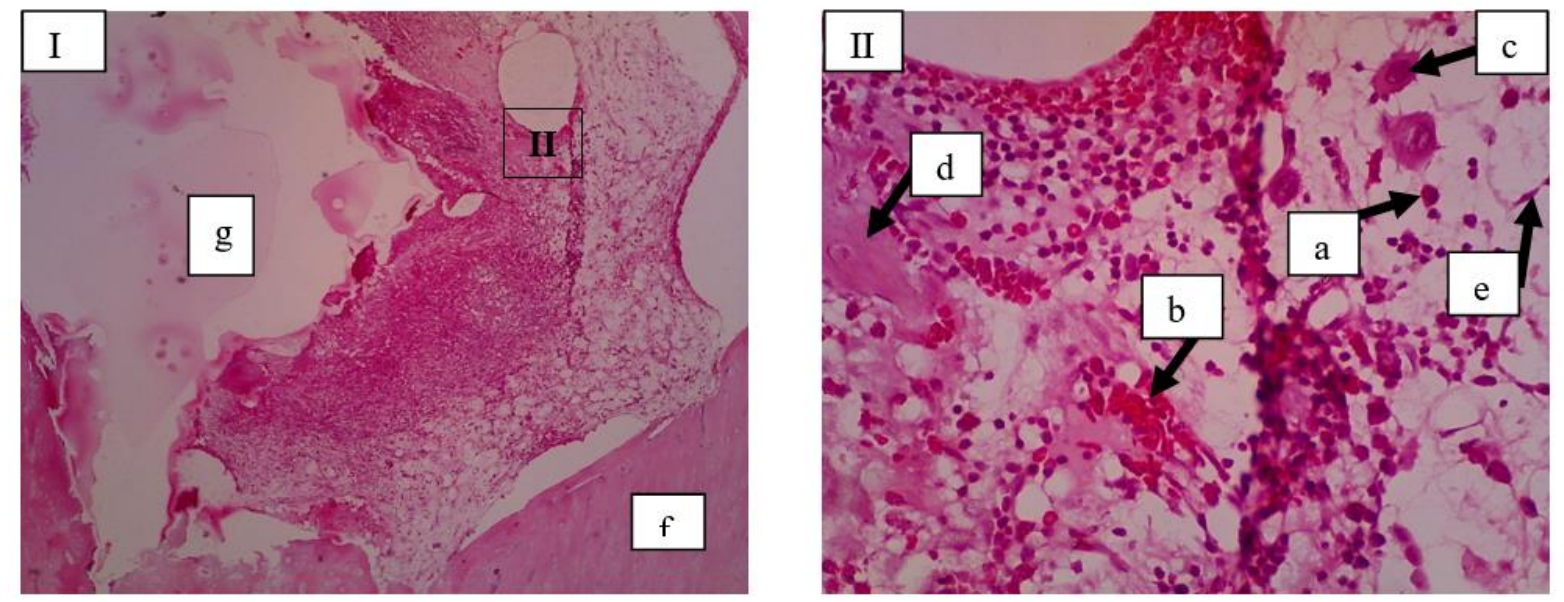

Gambar 2. Gambaran mikroskopis tulang kelinci pada lokasi implantasi bahan cangkok (Kelompok B) minggu ke-2. Pada lokasi implan mulai ditemukan kalus interna namun belum memenuhi ruang fraktur dan terlihat adanya sedikit sel radang (a), neovaskularisasi (b), osteoklas (c), spikula (d) dan fibroblas (e), tulang resipien (f), bone graft (g) (I: HE 10x; II: HE 40x). 

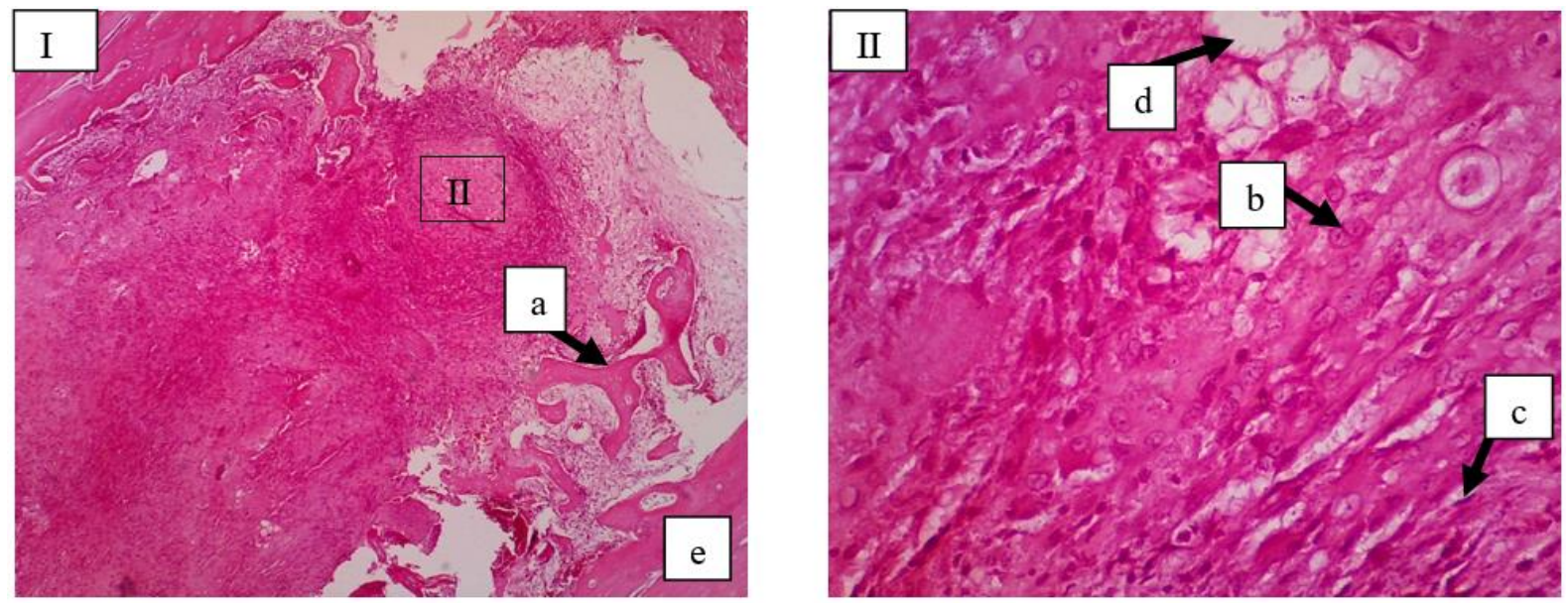

Gambar 3. Gambaran mikroskopis tulang kelinci kelompok kontrol (Kelompok A) minggu ke4. Pada lokasi fraktur mulai ditemukan kalus interna dengan terlihat adanya tulang trabekula (a), kartilago (b), fibroblas (c) dan sel lemak (d), tulang resipien (e) (I: HE 10x; II: HE 40x).
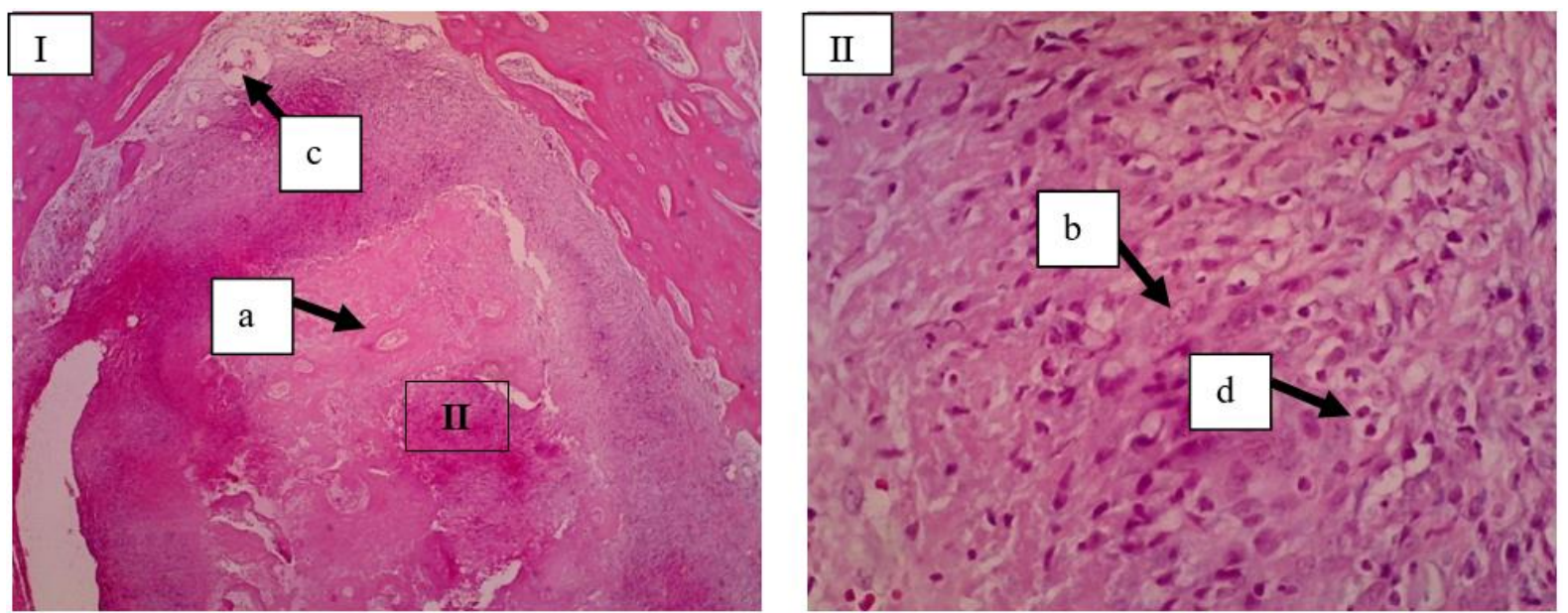

Gambar 4. Gambaran mikroskopis tulang kelinci pada lokasi implantasi bahan cangkok (Kelompok B) minggu ke-4. Pada lokasi implan kalus interna mulai memenuhi ruang fraktur dengan terlihat adanya tulang trabekula (a), kartilago (b), neovaskularisasi (c), fibroblas, osteosit, dan osteoblas (d) (I: HE 10x; II: HE 40x).
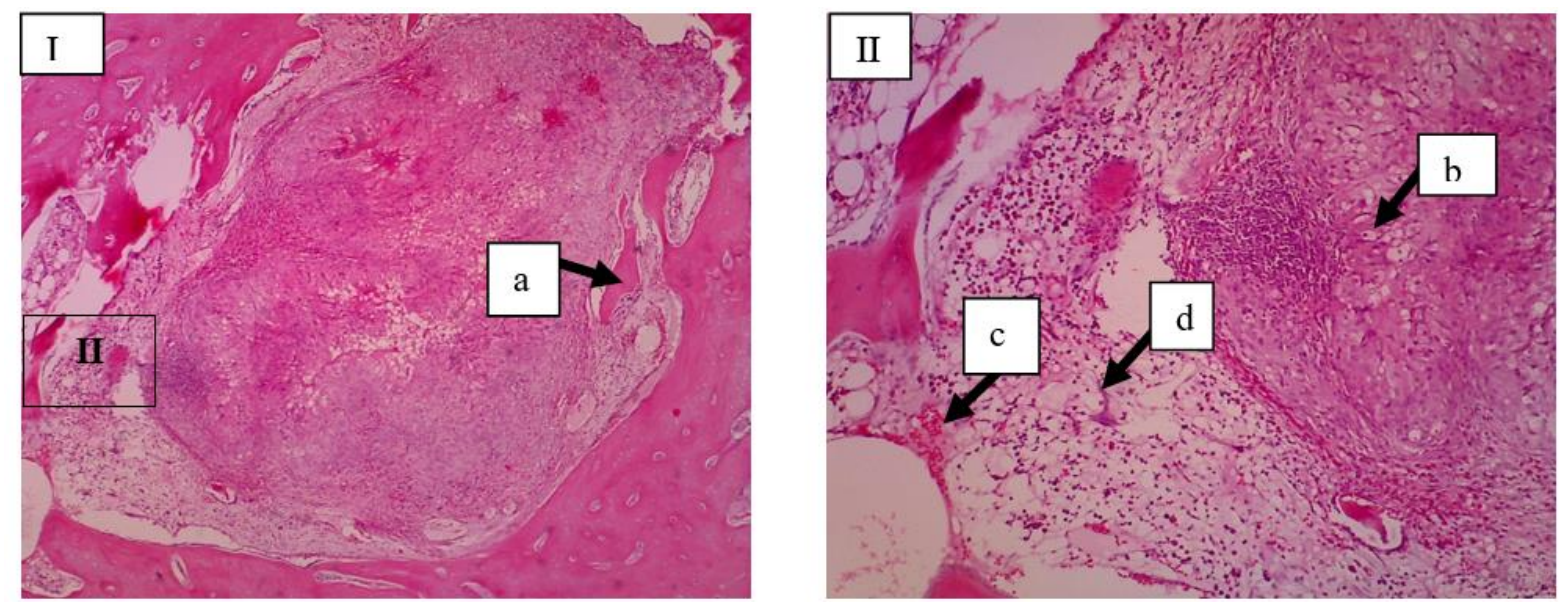

Gambar 5. Gambaran mikroskopis tulang kelinci kelompok kontrol (Kelompok A) minggu ke6. Pada lokasi fraktur kalus interna mulai memenuhi ruang fraktur dengan terlihat adanya tulang trabekula (a), kartilago (b), neovaskularisasi (c), fibroblas (d) (I: HE 10x; II: HE 20x). 

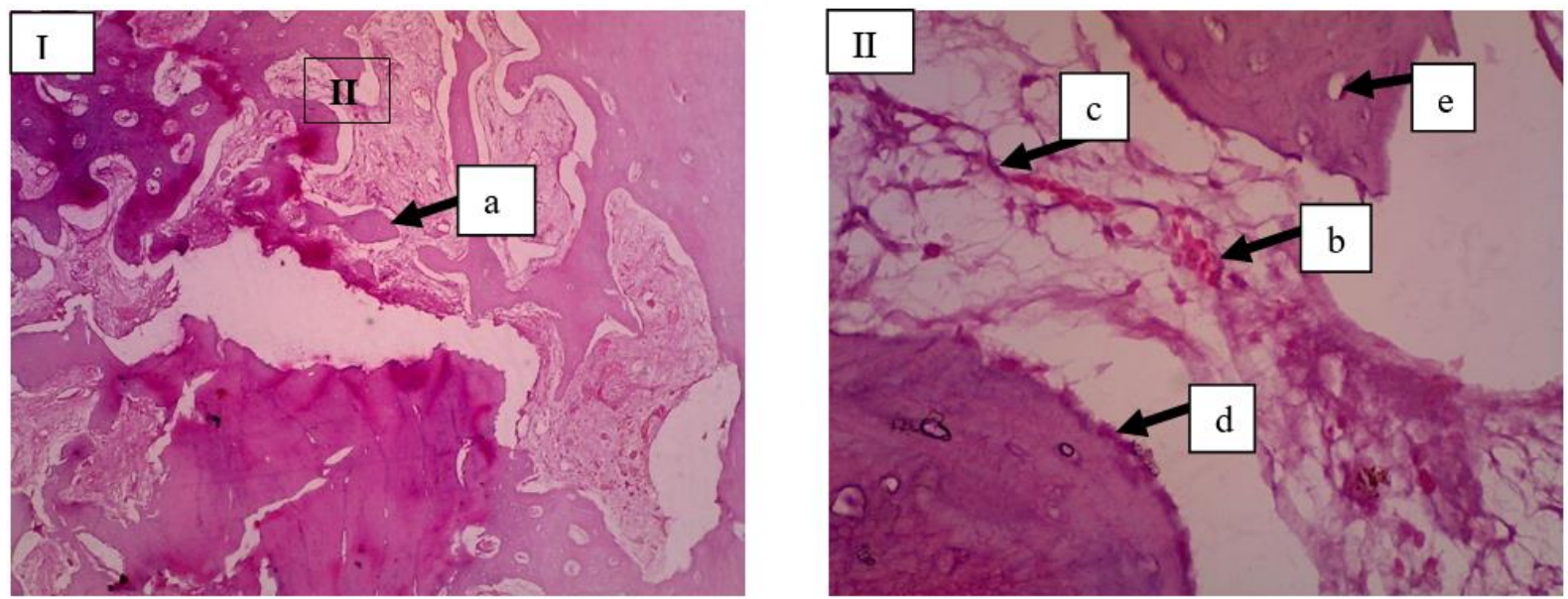

Gambar 6. Gambaran mikroskopis tulang kelinci pada lokasi implantasi bahan cangkok (Kelompok B) minggu ke-6. Pada lokasi implan woven bone digantikan oleh tulang kompak dan memenuhi ruang fraktur dengan terlihat adanya tulang trabekula (a), neovaskularisasi (b), fibroblas (c), peningkatan osteoblas (d), dan osteosit (e) (I: HE 10x; II: HE 40x).

Pada kelompok kontrol minggu ke-2 terlihat adanya banyak infiltrasi sel radang monomorfonuclear yakni makrofag dan limfosit serta sel radang polimorfonuclear yakni neutrophil (Gambar 1). Pada kelompok perlakuan minggu ke-2 terlihat adanya osteoklas, spikula, fibroblas dan neovaskularisasi serta tingkat infiltrasi sel radang lebih sedikit (Gambar 2). Fibroblas muncul dikarenakan sel fibroblas mensekresikan sitokin dan beberapa faktor pertumbuhan (growth factors) diantaranya dapat menstimulasi proliferasi sel dan menghambat proses diferensiasi (Wildmann et al., 2007). Choi et al. (2008), juga menjelaskan bahwa fibroblas memainkan peran penting dalam pengembangan sistem vaskular, saraf, dan skeletal, meningkatkan pemeliharaan dan kelangsungan hidup jaringan tertentu, dan merangsang penyembuhan luka dan perbaikan jaringan. Adanya fibroblas juga menstimulasi pembentukan callus, yang memberikan stabilitas mekanis pada fraktur, mempercepat penyembuhan, dan mengembalikan kompetensi tulang (Choi et $a l ., 2008)$. Selain fibroblas terlihat adanya neovaskularisasi, yang merupakan proses pembentukan pembuluh darah baru berupa tunas-tunas yang terbentuk dari pembuluh darah dan akan berkembang menjadi percabangan baru pada jaringan. Neovaskularisasi akan saling beranastomosis dan membentuk suatu jaringan sirkulasi darah yang padat pada jaringan. Pembuluh darah memiliki peran penting dalam proses kesembuhan tulang untuk memberikan asupan nutrisi yaitu kalsium bagi jaringan yang sedang beregenerasi (Reinke, 2012).

Pada minggu ke-4 terjadi penurunan jumlah infiltrasi sel radang pada semua kelompok dan penurunan jumlah infiltrasi sel radang lebih cepat terjadi pada kelompok perlakuan. Hal ini ditandai dengan sel radang mononuclear pada tulang femur yang diberikan bahan cangkok maupun tanpa bahan cangkok sudah menurun. Selain itu adanya sel-sel kartilago atau tulang fibrosa (woven bone) menandakan terjadinya fase kesembuhan tulang pada kelompok kontrol (Gambar 3). Pada kelompok perlakuan minggu ke- 4 terlihat adanya neovaskularisasi, fibroblas, kartilago, tulang trabekula osteoblas dan osteosit (Gambar 4). Hal ini sesuai penelitian Mahyudin et al. (2017), bahwa pada minggu ke-4 terlihat adanya jaringan fibrosa dan tulang fibrosa (woven bone), yang menandakan mulainya proses kalsifikasi. Salamanca et al. (2018), juga berpendapat pada tahap ini memungkinkan untuk mengamati sel-sel inflamasi dan sebagian besar tulang fibrosa (woven bone) dikelilingi oleh osteoblas. Pada minggu selanjutnya jaringan fibrosa dan tulang 
fibrosa (woven bone) menurun dengan tulang fibrosa (woven bone) tipis yang sudah terkalsifikasi (Mahyudin et al., 2017).

Pada kelompok perlakuan di minggu ke-6 terjadi peningkatan osteoblas, dan osteosit karena pertumbuhan tulang baru yang lebih intens pasca tulang tersebut diberikan bahan cangkok (Gambar 6) dibandingkan dengan kelompok kontrol dan pada semua kelompok perlakuan di minggu ke-4. Pada kelompok perlakuan minggu ke-6 sel radang tidak tampak yang menandakan peningkatan proses kesembuhan tulang. Pada penyembuhan tulang, Vascular Endothelial Growth Factor (VEGF) sangat diperlukan untuk membentuk mikrovaskular. Hal tersebut akan mempercepat fagositosis oleh osteoklas, diikuti dengan peningkatan osteoblas yang akan mempercepat pembentukan tulang fibrosa (woven bone) dan degradasi jaringan fibrosa (Kinney et al., 2010). Pada penelitian Mahyudin et al. (2017) dijelaskan bahwa sebelum penyembuhan tulang terjadi peningkatan osteoblas, osteoklas serta terbentuknya tulang fibrosa (woven bone), selanjutnya tulang fibrosa (woven bone) akan berkurang pada minggu berikutnya karena porses kalsifikasi. Proses pembentukan callus mulai terjadi dari minggu kedua dan terjadi secara maksimum pada minggu keenam bersamaan dengan kalsifikasi hingga penyembuhan terjadi. Ada 2 cara pembentukan tulang yaitu osifikasi intramembranous dan osifikasi endokondral (intrakartilago) Mackie et al. (2008). Osifikasi intramembranous adalah proses yang terjadi pada sel mesenkim yang berdiferensiasi menjadi osteoblas di pusat ossifikasi secara langsung tanpa pembentukan kartilago terlebih dahulu sedangkan osifikasi endokondral (intrakartilago) yaitu proses pembentukan tulang yang terjadi dimana sel-sel mesenkim berdiferensiasi lebih dulu menjadi kartilago (jaringan rawan) lalu berubah menjadi jaringan tulang Mackie et al., (2008).

Pada penelitian ini bahan cangkok yang diberikan pada diaphysis femur kelinci mampu mempercepat proses fraktur healing yang dibuktikan terbentuknya neovaskularisasi, tulang trabekula, osteoblas, osteoklas, dan osteosit. Hal ini sesuai dengan penelitian yang dilakukan oleh Puricelli et al. (2010) dimana demineralized bone graft mampu mempercepat proses fraktur healing dengan baik mulai 30-60 hari pasca implantasi. Menurut Wildmann et al. (2007), berbagai bahan cangkok tulang digunakan untuk tujuan meningkatkan kemampuan tulang dan penyembuhan tulang. Penyebab bahan cangkok mampu mempercepat proses fraktur healing karena selain mengandung Bone Morphogenetic Proteins (BMPs) suatu protein hyodrophobic dalam matriks tulang yang mempengaruhi diferensiasi sel mesenkim menjadi osteoblas yang ikut dalam proses penyembuhan tulang baru, bahan cangkok juga mengandung platelet derived growth factor (PDGF) dan fibroblas growth factor (FGF) sehingga proliferasi fibroblas lebih cepat terpacu dan pembentukan kartilago lebih luas. Selain itu bahan cangkok juga mengandung vascular endothelial growth factor (VEGF) yang memicu proses vaskularisasi (Wildmann et al., 2007).

Menurut McAllister dan Haghighat (2007), penggunaan bahan cangkok didasarkan pada asumsi sebagai bahan regeneratif yang memiliki potensi osteogenik (mengandung sel pembentuk tulang), bersifat osteoinduksi (mengandung substansi induksi tulang), atau osteokonduksi (membentuk scaffold pada formasi tulang). Bahan anorganik dari bovine bone graft mampu mendukung perlekatan dan proliferasi sel-sel osteoblas, yang merupakan langkah awal untuk proses osteogenesis. Menurut Ramirez-Fernandez et al. (2011), salah satu faktor yang mempengaruhi osteokonduksi dalam kesembuhan fraktur adalah ukuran serbuk 
dari bahan cangkok. Ukuran bahan cangkok yang tergolong kecil memudahkan sel tulang terjembatani melalui bahan cangkok. Seperti penelitian dari McAllister and Haghighat (2007), penelitian ini juga menunjukkan bahwa xenograft bersifat osteoinduksi yang ditandai dengan proliferasi sel-sel osteoblas pada minggu ke-6 kelompok perlakuan.

\section{SIMPULAN}

Bahan cangkok demineralisasi asal tulang sapi bali mampu menginduksi proses kesembuhan fraktur tulang femur pada kelinci yang diamati secara mikroskopis.

\section{SARAN}

Perlu dilakukan penelitian lanjutan dengan waktu pengamatan yang lebih lama untuk mengetahui efek samping penggunaan bahan cangkok asal serbuk tulang sapi serta penelitian pembanding dengan menggunakan bahan cangkok komersial yang sudah ada dipasaran.

\section{UCAPAN TERIMAKASIH}

Penulis mengucapkan terima kasih terutama kepada semua pihak yang telah membantu dalam penyelesaian penelitian ini.

\section{DAFTAR PUSTAKA}

Choi SC, Kim SJ, Choi JH, Park CY, Shim W. 2008. Fibroblast growth factor-2 and -4 promote the proliferation of bone marrow mesenchymal stem cell by the activation of the pi3k-akt and erk $1 / 2$ signaling pathways. Stem Cell Develop. 17: 725-736.

Greenwald AS, Bode SD, Goldberg VM, Yaszemki M, Heim CS. 2008. Bonegraft substitutes: Fact, fictions and applications. $75^{\text {th }}$ Annual Meeting American Academy of Orthopaedic Surgeons.

Heo SH, Na CS, Kim NS. 2011. Evaluation of equine cortical bone transplantation in a canine fracture model. Vet. Med. 56(3): 110-118.

Kaewloet LN. 2008. The correlation between affecting factors and wound healing rate in diabetic foot ulcer. Faculty of Graduate Studies. Mahidot University. India

Mackie E J, Ahmed YA, Tatarczuch L, Chen KS, Mirams M. 2008. Endochondral ossification: How cartilage is converted into bone in the developing skeleton. Int. J. Biochem. Cell Biol. 40: 46-62.

Mahyudin F, Utomo DN, Suroto H, Martanto TW, Edward M, Gaol IL. 2017. Comparative effectiveness of bone grafting using xenograft freezedried cortical bovine, allograft freezedried cortical new zealand white rabbit, xenograft hydroxyapatite bovine, and xenograft demineralized bone matrix bovine in bone defect of femoral diaphysis of white rabbit: Experimental study in vivo. Int. J. Biomater. 2017: 7571523.

McAllister BS, Haghighat K. 2007. Bone augmentation techniques. $J$. Periodontal. 78: 377-96.

Pilitsis JG, Lucas DR, Rengachary SR. 2002. Bone healing and spinal fusion. Neurosurg. Focus. 6(1): 1-6.

Puricelli E, Corsetti A, Ponzoni D, Martins GL, Leite GM, Santos LA. 2010. Characterization of bone repair in rat femur after treatment with calcium phosphate cement and autogenous bone graft. J. Head Face Med. 6: 10.

Ramirez-Fernandez MP, Calvo-Guirado JL, Delgado-Ruiz RA, Val JEM-Sd. 2011. Experimental model of bone response to xenografts ofbovine origin (Endobon ${ }^{\circledR}$ ): a radiological and histomorphometric study. Clin. Oral Imp. Res. 22: 717-734.

Kinney RC, Ziran BH, Hirshorn K, Schlatterer D, Ganey T. 2010. Demineralized bone matrix for fracture healing: fact or fiction?. J. Ortho. Trauma. 24(1): S52-S55.

Reinke JM, Sorg H. 2012. Wound repair and regeneration. Eur. Surg. Res. 49: 35-43.

Salamanca EC, Hsu H, Huang N, Teng C, Lin Y Pan, dan W Chang. 2018. Bone 
regeneration using a porcine bone substitute collagen composite in vitro and in vivo. Sci. Rep. 8: 984.

Wildmann B, Kadow RA, Haas NP, and Schmidmaier G. 2007. Quantification of various growth factors in different demineralized bone matrix preparation. J. Biomed. Mater. Res. A. 81(2): 437-
442.

Wirata IW, Sudimartini LM, Gunawan IWNF. 2016. Bahan cangkok demineralized freeze-dried bovine bone xenograft (DFDBBX) dan hydroxyapatite bovine bone xenograft $(H A-B B X)$. Universitas Udayana. 